\title{
THE INFLUENCE OF ISLAMIC ETHICAL RETURN, INVESTMENT AND FIRM
} VALUE

Wahyu Febri RS.

State Islamic University of

Maulana Malik Ibrahim

Malang, Indonesia

\section{Basir Sagena}

State Islamic University of

Maulana Malik Ibrahim

Malang, Indonesia

E-mail:

basirsagena@yahoo.co.id

Mareta Eka Prajawati

State Islamic University of

Maulana Malik Ibrahim

Malang, Indonesia

\begin{abstract}
Interest of investors in investing in the stock market is to get a rate of return as an element of revenue. Given this background, this study was to decide the influence of ethical Islamic return on investment and the value of the company, as well as the effect of the investment on firm value. The research was conducted on companies listed in the Jakarta Islämic Index for the period 2012-2015. The results showed an increase in income of non-kosher will lower the interest of investors to invest, increase the amount of revenue non-kosher will lower the value of the company, an increase in the deviation of investment according to Islāmic principles have a negative significant effect on the company value, and increasing the amount of income halal through investments based on the principles of sharia will enhance shareholder value.
\end{abstract}

Keywords: Islamic ethical return, invesment, firm value.

| Received January 2018 | Accepted March 2018 | Available online April 2018 |

| DOI: http://dx.doi.org (Editor only)

\section{INTRODUCTION}

Enterprise as an economic entity typically has short-term goals and long-term. In the short term goal of gaining profit firms optimally using existing resources, while in the long term the company's main goal is to maximize the value of the company, so it will create prosperity for our shareholders. The value of the company will be drawn from the relevant company's stock price. Martono and Agus (2005) in Rica (2010) and Alfredo (2011) explains that the establishment of a company has a clear goal, the company's goal was the first to achieve the maximum benefit or profit as much as possible, want to prosper owner of the company or the shareholders and maximize the value of the company is reflected in its share price. The third goal the company is actually substantially not much different. Another policy with regard to the value of the company is an investment decision. Conduct of investment activities is the hardest decision for the management of the company because it will affect the value of the company (Vranakis and Prodromos, 2012). The purpose of the investment decision is received huge profits with risks that can be managed with the hope to optimize the value of the company (Afzal and Abdul, 2012).

The main differences of Islamic ethical return (return based on the ethics of Islam) against conventional investment is an operational process, and the most basic is the screening process in formulating the portfolio. Screening based syariah include qualitative and quantitative aspects. Filtering on the qualitative aspects include the content Asset value whether or not a company engaged in a sector; whether in practice, it uses the element of usury; and whether in practice it uses maysir and gharar. While filtering the quantitative aspects of the criteria on the financial aspects of the company is composed of the aspects of capital, debt and corporate earnings (Hanaafi 2011). Purpose or motivation of investors in investing in the stock market is to get a rate 
of return (return) as an element of revenue. Measurement of return provides two advantages for investors. The first advantage, measurement return allows the investor to know their success in making an investment. Second, the measurement of return also played a role in predicting future returns. Therefore, the return is used to assess a wide range of alternative investments.

Management should pay attention to two important things in fungi principal finance companies is how to obtain the source of funds and how the use of funds, so the motivation of authors in this study are as follows: First: to maximize the welfare of shareholders through maximizing the value of the company without ignoring Falah for all mankind in maqashid as-Syariah perspective. Second: investment decisions are not just talking about a few material benefits (returns) to be had from investing activities, but more investment activities are based on social motives to enhance shareholder value. Third: to see the consistency of prior research and develop some previous studies with the approach, objects and different methods of analysis. Fourth: This study is a renewal and expansion of several previous studies. Renewal is done with the intention to provide additional empirical evidence on the relationship of financial decisions through the aspects of ethical values and religion. The purpose of this study was to determine the effect of ethical Islamic return on investment and the value of the company, as well as to determine the effect of investment on firm value.

\section{LITERATURE REVIEW AND HYPOTESHIS}

\section{Decision Making: A Behavioral Approach}

Simon (1995) as the originator of Bounded Rationality is a novice in the science of behavior and then dug up and controlled more by scientists. The concept of decision-making, developed by Kahneman and Taversky (1967) connects the financial aspects with aspects psychology is known as behavioral finance (Behaviour of Finance). Kahneman and Taversky (1967) states that investors are always influenced by the character and personality in investing. It can be used as input to the financial interest and investment that people are not just always use financial logic mathematically in conducting economic, more than that one of the things that affect investment activity is character psychology person to perform investment activities.

\section{Islamic Ethical Return (Return Based on Islamic Ethics)}

According to Basir (2015) The main differences of Islamic ethical return (return based on the ethics of Islam) against conventional investment is an oprational process, and the most basic is the screening process in formulating the portfolio. Screening based syariah include qualitative and quantitative aspects. Filtering on the qualitative aspects of the content assets include judgment, 1) if the company is engaged in sectors that are prohibited or not; 2) whether, in practice, using elements of usury; 3 ) whether in practice using the maysir and gharar.

\section{Investment}

Logue (1973) introduced the theory of underpricing shares when the company conducted an IPO and their initial return on the first day on the exchange. The securities company does not want his investors ran for the shares offered to make investor losses. Then came the theory linking financial and psychology is known as the theory of financial behavior (behavior of finance). Shefrin (2000) defines the behavior finance is the study of how psychology affects behavior phenomena finances. The behavior of the players of these shares which states Shefrin behavior level practitioners.

According to sharia investment, there are other things that play a role in investment. Islamic investment not only oriented to any worldly interests as expressed by economists secular. 
Moreover, there are other things that determine the success of an investment in the future, namely the provision and the will of God. As embodied in the QS. Al-Luqman verse 34. That's what separates the Islamic and conventional investment investment. Investments that Islam is is the sacrifice of the resources at present to obtain definitive results, with the hope, obtain greater results in the future, either directly or indirectly, while still adhering to the principles of sharia as a whole (kaffah), Besides any form of investment, is based on the worship of God to reach the outer and inner happiness in this world and in the hereafter.

\section{The Concept of Value In Maqasid As-Sharia}

Etymologically maqasid al-shariah consists of two words maqasid and sharia. Maqhasid plural of maqsudh meaning intent or purpose. The syaraiah means the road to the spring, or it could be interpreted as a direction toward the road of life. While the terminology, some notion of maqasid al-shariah raised by some scholars earlier, as imam al-Ghazali defines maqasid al-shariah as a guard against the aims and objectives of sharia is an effort fundamental to survive, resist factors damage and encouraging welfare.

The benefit to be achieved by sharia are general and universal, general means it applies not only to private individuals but also for all of humanity. Universal means applies to the level of a certain period only, but the whole of human life. Therefore, Allah does not immediately order something to man but there is a benefit in it. If a law there is no benefit in it, then certainly it is not the law of Allah SWT.

Research conducted by Komala and Nugroho (2013) with the title The effect of profitability ratios, liquidity and debt towards investment return. This study was conducted to examine the influence of fundamental factors in making investments that are measured by the dividend payout ratio for companies listed on the Indonesia Stock Exchange. The results showed that the return has a significant negative effect on investment. The hypothesis of this study is: $\mathrm{H} 1$ : Islamic ethical return a significant effect on the desire to invest.

Research conducted by Aisyatul and Maswar (2014) showed that the Return On Asset (ROA) significant negative effect on firm value, Return on Equity (ROE) and Net Profit Margin (NPM) significant positive effect on firm value, variable Corporate SocialResponsibility not afford to affect the relationship between the Return on Asset (ROA) and Net Profit Margin (NPM) to corporate value, while variable Corporate SocialResponsibility capable of affecting the relationship between the Return on Equity (ROE) to corporate value. The hypothesis of this study is $\mathrm{H}_{2}$ : Islamic ethical return a significant effect on the value of the company.

Research conducted by Lin and Kulaltilaka (2007) with the title of Strategic options and firm value. This study discusses how companies make investment decisions on the value of the company on the company network industry. Game-theoretic models are used as an analysis tool with the variables used are investment decisions and value of the company. With hail, which negatively affects the investment value of the company, because of the high intensity on the network lowers investment threshold and the expected value of the company. Hipotesis of this study are:H3: Investment based on the principle - the principle of sharia affect the value of the company.

Research conducted by Rahim et al., (2010) examined the impact of investment governance and board governance on company valuation. Results from these studies show that investment is positively related to the value of the company, board governance, profitability is negatively related to the value of the company, leverage, dividends, free cash flow was positively related to the value of the company. Overall this study suggests that the value of the company will be increased through a reduction in agency costs through the monitoring mechanism, debt agreements and implement investment strategies that secure (by avoiding risky investment) as 
well as ensuring that excess cash is distributed to holders of Saham. This research shows that return has a negative effect and significant investment. $\mathrm{H} 4$ : Islamic ethical return affect the value of the company through investment based on the principles of sharia.

Figure 1. Conceptual Model

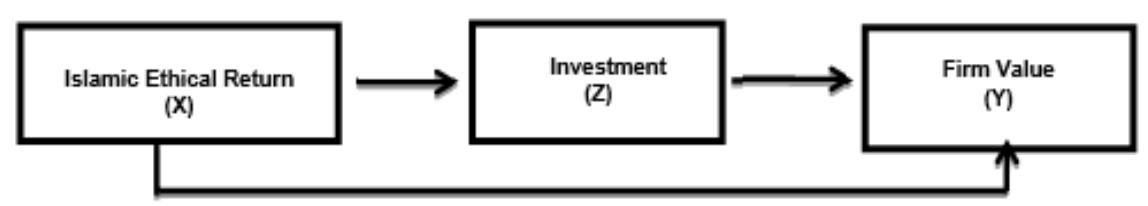

\section{METHOD}

This research used a quantitative approach in an effort to test the hypotheses that have been prepared. Much quantitative research is required to use numbers from the collection of data, the interpretation of such data as well as the appearance of the results (Arikunto, 2006). The object of research used in this study are all companies incorporated in the index Jakarta Islamic Index (JII) in 2015 which always come into $\mathrm{JII}$ index continuously during the period 2012-2015. The data taken is a data panel that incorporates data time series (time series) and a cross section of 20 issuers, so that the number of research data is 80 .

\section{Variable Operational Definition}

\section{Islamic Ethical Return (Return based on the ethics of Islam)}

The rate of profit (return) of the total revenue is motivation investor in making an investment because the return is often used as a benchmark to compare alternative investment. If the loan companies use the system in addition to own capital will lead to the rise of interest income, the total interest income, and other lawful income does not compare to total income (revenue) of halal muamalah processes in internal company or of a process for the results of the company's investment and rental (fee) which is not greater than $10 \%$.This means that this ratio is used to measure the effectiveness and overall enterprise with Islamic Sharia principles are ethical returns (Basir, 2015). The formula is:

$$
\text { Islamic ethical return }=\frac{\text { interest income }}{\text { total revenue }}
$$

\section{Investment}

Investment is the total amount of funds in the period of the period which should be used both in the real assets or the financial assets invested by the company with the hope of gain. Shariabased company is required to carry out investment activities are conducted free of usury. The higher the ratio against usury-free investment to total investment, will have a positive impact on the reduction of inequalities of income and wealth in society. So investing in this study was measured through iqamah al-Adl. The formula used is:

$$
\text { Iqamah al-adl }=\frac{\text { interest free income }}{\text { totalincome }}
$$

Firm Value

16 Management and Economics Journal (MEC-J)

Vol 3 (1) April 2019 
Maximizing the value of the company is one of the goals to be achieved by the company in order to maximize the welfare of the owners of capital. The company's value is not only measured through past value but also can be measured by sharia aspects. For the welfare of the company stakeholder, community and social environment are the goal that must be achieved, so that the value of the company in this study was measured using the approach justice purposes (Maqasid al-Sharia). The formula used is:

$$
\text { Maqashid as-syariah }=\frac{\text { CSR Fund }}{\text { net income }}
$$

We use path analysis (path analysis). Path analysis correlation is broken down into several interpretations consequences thereof. Path analysis is a technique for analyzing the causal relationships that occur in multiple regression if the independent variables affect the dependent variable not only directly, but also indirectly (Sarwono, 2007).

\section{RESULTS}

Data Analysis and Hypothesis Result

Table 1. Statistics

\begin{tabular}{|c|c|c|c|}
\hline & Islamic Ethical Return & Investasi & Nilai Perusahaan \\
\hline $\begin{array}{l}\text { N Valid } \\
\text { Mean } \\
\text { Median } \\
\text { Mode } \\
\text { Minimum } \\
\text { Maximum }\end{array}$ & $\begin{array}{l}65 \\
0 \\
.040037 \\
.034800 \\
.0013 a \\
.0013 \\
.0952 \\
\end{array}$ & \begin{tabular}{|l}
65 \\
0 \\
.945831 \\
.954000 \\
.95310 \\
.8322 \\
.9983 \\
\end{tabular} & $\begin{array}{l}65 \\
0 \\
.047614 \\
.034300 \\
.0153 \\
.0001 \\
.2640 \\
\end{array}$ \\
\hline
\end{tabular}

Multiple modes exist. The smallest value is shown

The average ratio of the company's revenue is based on Islamic ethical returns that were sampled from 2012 to 2015 (4 years) amounted to 3.48\%, meaning that if the company earned a total revenue of $£ 100$, -, then $£ 3.48$ of the total income is income interest and other the income of non-kosher. Based on the data obtained, the average interest income during the observation year 2012 to 2015 was in 2014 of 0.13 , while the highest value in 2014 amounted to 9.52 .

The average ratio of usury-free investment during the observation period 2012 to 2015 (4 years) amounted to $95.4 \%$, meaning that if the company earned a total income of as much as $£ 100$, -, then $£ 95.22$ from the total income of an interest-free income. Based on the data obtained, the average interest in low-income submarine observations in 2012 until 2015 was the year 2014 amounted to $83.22 \%$, while the highest value in 2015 amounted to $99.83 \%$.Based on the statistical calculation, the average value of the company on the observation period 2012 to 2015 (4 years) of $3.43 \%$, meaning that the company issue $3.43 \%$ of total net revenue as the cost of social responsibility. Lowest enterprise value was shown in 2014 by $0.1 \%$, while the highest value of the company is shown in 2014 of $26.4 \%$.

Hypothesis testing is done by using path analysis software SPSS 20 the results are presented in table figure 2 below: 
Figure 2. Path diagram

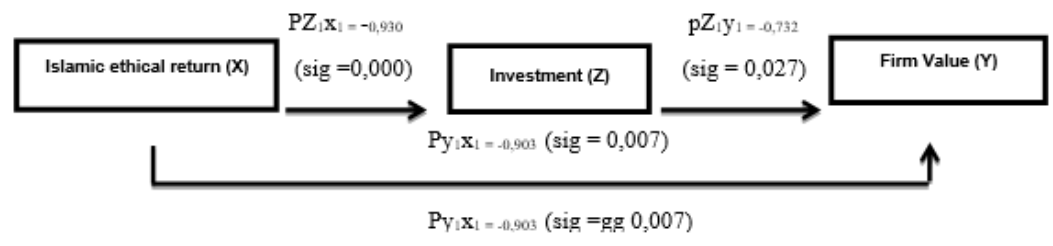

In addition to Direct Impact Test (Direct Effect), in the path analysis also known indirect effect (indirect effect) and the effect of the total (total effect). The indirect effect is the multiplication of two direct influences that shape is significant. From the calculation of the indirect effect of a variable ethical Islamic return to corporate value through investment, is a significant and positive influence to standardize coefficient of 0.68076 .

\section{DISCUSSION}

\section{The Influence of Islamic Ethical Return and Investment}

The results of this study stated that ethical Islamic return significant negative effect on investment. The smaller the interest income in the Islamic ethical return hence the desire to invest based on the principles of sharia will be even greater. Basically, flowers also gave the advantage to the investor or the owner of the funds. Profit to be received by investors of the interest, of course, different from the benefits of the results. Gains will be accepted regardless of its interest to the work of the financed party, otherwise, the benefits of the results will change over from the operating results obtained by the party funding. Through a system of revenue sharing between investors and parties receive funds will benefit from a fair share in accordance with the agreement that has been made.

Investment in Islam is an investment approach that is lawful and thayyib, which have nothing to do usury therein. Investments were unclean allows capital used to contain substances that dirty or from the proceeds of crime. Investments in which mixed elements of clean and unclean was not justified in Islam because capital investment using kosher but pda practice using the transaction and the contract is broken then it will be broken anyway. As described in Al-Baqarah verse 207 which confirms that all that we do and treasure invested solely to seek the blessing of Allah SWT. Islam forbids invest treasure when the results are not halal and haram full element. Therefore, in implementation call, these investments must be made of the means to invest Sesua with the teachings of Islam.

This study supports research conducted by Komala and Nugroho (2013) which showed that the return has a negative and significant effect on resisting investors.Penelitian research conducted by Khoramin, et al., (2013) which showed that significantly influence the profitability of investment opportunities, meaning that the greater the chance of making investments for the company, it will provide great returns.

\section{The Influence of Islamic Ethical Values Return to Company}

The results of this study indicate that the ethical Islamic return a significant negative effect to firm value, the greater the non-kosher income earned by the company, the enterprise value would be diminished. Revenue generated from financial activities are expected to not stir to mix between income kosher and non-kosher, because in Islam do not base on financial activity to get huge profits, but also gain huge profits by way blessed by Allah SWT.

18 Management and Economics Journal (MEC-J)

Vol 3 (1) April 2019 
Islam set up a very strong relationship between morality, faith, worship and muamalah (Djakfar, 2012). Muamalah aspect is the rule for man in running social life, at once the foundation for building an economic system in accordance with the values of Islam. Doctrine muamalah will hold human beings in all the methods to obtain sustenance. Tenets taught a man in getting lawful and good sustenance. Economic behavior is far from religious values that gave birth to the unequal economic life and environmental damage that would threaten the survival of future generations.

\section{Influence against Investment Company Value}

The capital investment is one of the main aspects of investment decision other than the determination of the composition of the assets. Capital allocation decisions into investment proposals must be evaluated and associated with the risk and expected results Hasnawati (2005). The company's goal in investing is to earn profits in the future. Then these investments will be assessed and how far invested deliver results to corporate value.

The results of this study indicate that the investment significant negative effect on the value of the company. That is, the greater the deviation of investment according to the principles will cause a decrease in the value of the company. Investment activity is real and financial investment is expected according to the principles or rules of Sharia, thus causing the value of the company will meningkat.Investasi muamalah in Islam is an activity which is highly recommended, because the property owned beinvestasi be productive and also provide benefits for others.

In the Islamic economic perspective investments not only tells of material benefit to be gained from such investments. More investment activities based on social motivation is to help some people who do not have the capital but has the ability and the form of expertise in running a business, whether in the form musyarakah or for the results. Islam also called on the economic activity that does not damage the environment, in the sense that any investment activities that are damaging to the environment is forbidden in Islam. But in fact a lot of investments that are in the world and finally the impact of the environmental destruction resulting negative effect on life as represented the word of God in Sura Ar-Rum verse 41.

\section{Islamic Influence Ethical Return to Corporate Value through Investment}

Gain or profit in real investment activities or financial investments is motive an investor in investing the money. financial investments usually take the form of investments in other companies through the activities of securities or in bank deposits, which will increase the wealth in the form of profit that will increase the value of the company. The company's goal in investing is to earn profits in the future. Then these investments will be assessed and how far invested deliver results to corporate value. The results of this study indicate that the ethical Islamic return positive significant effect on the value of the Vendor through investment. That is, the greater the revenue earned by the company kosher through investment activities based on the principles of sharia will enhance shareholder value.

There are several ways to invest in the company, maybe the turn of ASAT, expansion, the addition of other forms or products according to the needs of companies which capital to be issued for the purchase or cultivation of assets with the hope will benefit the company. In the perspective of the Islamic economic benefit or profit is a good profit which is not contained elements inside it unclean and khibbas (gross) that is to say, the income must be halal should not be mixed with illicit earnings. Islam pushes economic growth caused by the growth of the real business. Rill business growth will have a positive influence on the division results received by some people to make investments. Distribution of the results of operations can be applied in the form of profit sharing. For an acceptable result in the results would benefit the owners of capital to get the funds in investments. 


\section{CONCLUSION}

In this article, the authors explore the relationship between Islamic ethical return on investment and the value of the company. This study shows that the increase in non-kosher revenue will lower the interest of investors to invest. Increasing the number of non-kosher revenue will decrease the value of the Investment Company. grow deviation according to Islamic principles negative significant effect on firm value. From the calculation of the indirect effect of a variable ethical Islamic return to corporate value through investment. Islamic influence ethical returns on corporate value through investment according to Islamic principles significantly positive. Therefore, an increase in the number of lawful income through investment based on the principles of sharia will increase the value of the company. More studies are called for to understand the causality in the relationship between Islamic ethical return, capital structure, ownership, and macroeconomic variables.

\section{REFERENCES}

Al-Qur'an

Al-Hadits Shahih At-Targhib.

Dusuki, Asyraf Wajdi and Irwani, Abdullah Nurdianawati. (2007). Maqashid as-Syariah, Maslahah and Corporate Social Responsibility. The American Journal of Islamic Social Scienci. 24 (1), $25-42$.

Herbert, Simon. (1955). Decision Making and Organizational Design in D.S Pugh (Eds). Organization Theory. Great Britain: Pinguin Education.

Ibbotson. (1975). Price Performance of Common Stock New Issues. Journal of Financial Economic, Vol. 2.

Kahneman, Daniel, and Amos Tversky. (1979). Prospect Theory: An Analysis of Decision under Risk. Econometrica, 47(2), 263-292.

Khoramin M., Ghodratolla Taleb Nia and Hamidreza VakiliFard. (2013). the Relationship between Profitability and Financial Flexibility, and Investment Opportunities and Dividend Policy in Companies Listed in Tehran Stock Exchange. Journal of Life Science and Biomedicine, Vol. 3(5) pp. 344-351.

Kohler, Matthias. (2013). Does Non-Interest Income Make Banks More Risky? Retail- Versus Investment-Oriented Banks. Bundesbank Discussion Paper No 17.

Komala dan Nugroho (2013). The effect of profitability ratio, liquidity and debt towards investment return. Jurnal Keauangan dan Bisnis.

Lin, Lihui and Nalin Kulatilaka. (2007). Strategic options and firm value. Managerial Finance, Vol. 33 Iss: 11 pp. $893-903$.

Logue, D. 1973. On the Pricing of Unseasoned Equity Issue: 1965-1969, Journal of Financial Quantitative Analysis. Vol 8. 91-103.

Nofsinger, John R. (2002). Investment Blunders of the Rich and Famous; Prentice Hall

Pillis E., D. and Reardon, K. K. (2007). The Influence of Personality Traits and Persuasive Message on Enterprenuerial Intention, Career Development International, Vol.12 No. 4, pp. 382396.

Pistrui, D., Huang, W., Oksoi, D., Zhao, J. and Welsch, H. (2006). Family and Cultural Forces Shaping Enterpreneurship and Private Enterprise Development in China. Joint Conference Proceedings, January 12-15, 2006, Tucson Arizona.

Rahim, Ruzita Abdul, Mohd. Hasimi Yaacob, Norazlan Alias and Fauzias Mat Nor. (2010). Investment, Board Governance and Firm Value: A Panel Data Analysis. Faculty of Economics and Business/Graduate School of Business. National University of Malaysia.

Shefrin, Hersh (2000); Beyond Greed and Fear: Understanding Behavioral Finance and Psychology of Investing; Harvard Business School Press

Shihab, Quraish. (2005). Tafsir Al-Misbah. Jakarta: Lentera Hati

20 Management and Economics Journal (MEC-J)

Vol 3 (1) April 2019 
Taormina, R. J. and Lao, S.K.M. (2007). Measuring Chinese Entrepreneurial Motivation: Personality and Environmental Influences. International Journal of Entrepreneurial Behavior and Research, Vol. 13 No. 4, 2007 pp. 200-221.

Vik, J. And McElwee, G. (2011). Diversification and the Entrepreneurial of Farmer in Norwey. Journal of Small Business and Management, 49 (3), pp. 390-410.

Vranakis, Stergios K and Prodromos D. Chatzoglou. (2012). A Conceptual Model for Machinery and Equipment Investment Decisions. International Journal ofBusiness and Management, 7(1): pp: 36-5. 
